\title{
Contralto: Rossini, Gautier and Gumilyov ${ }^{1}$
}

Contralto is a low sort of music that only ladies sing.

$-B O N E R S^{2}$

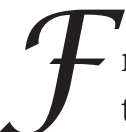

rom its inception the art of opera admitted casting singers in roles that depicted characters of the opposite sex. In early operas by Monteverdi and Cavalli, it was usual to have tenors in women's garments portray nurses and other elderly women on the apparent assumption that female voices acquire a deeper pitch in old age. During the heyday of Alessandro Scarlatti in the late seventeenth century and of Handel in the early eighteenth, opera composers had at their disposal two kinds of male singers who could perform in the range usually associated with female voices: the highly popular soprano and alto castrati. These men, through surgery undergone in childhood, retained the soprano or alto voice of a little boy, reinforced with the power and resonance of adult male lungs.

The conventions of the eighteenth century allowed for casting of castrati in male roles, such as Orpheus or Julius Caesar. The audiences of the time were quite accustomed to seeing the heroine of the opera (almost invariably a female soprano) in love with a character who looked-more or less-like a man but sounded like a woman. In the last decades of the eighteenth century, castrato singers appeared primarily in opera seria, the musical equivalent of neoclassical tragedy, with texts that were often based on successful plays of that species. When the fourteen-year-old Mozart received a commission to compose his first opera seria, Mitridate,

1 Originally published in Language, Literature, Linguistics: In Honor of Francis J. Whitfield, on His Seventieth Birthday, March 25, 1986, ed. M. S. Flier and S. Karlinsky (Berkeley: Berkeley Slavic Specialties, 1987), 128-41.

2 BONERS. Being a Collection of Schoolboy Wisdom. or Knowledge As It Is Sometimes Written, Compiled from Classrooms and Examination Papers by Alexander Abingdon, and Illustrated by Dr. Seuss (New York: Viking Press, 1931), 32. 
re di Ponto (after a tragedy by Racine), he had to tailor his music for a company whose four leading singers were two female sopranos and two castrati, one soprano and one alto. ${ }^{3}$ But even in the works of his maturity in opera seria form, the magnificent Idomeneo, composed at twenty-five, and the last opera he wrote, La clemenza di Tito, the roles of romantic young lovers were scored for alto castrati, while the roles of father figures (Idomeneus and the Emperor Titus), which would have been basso parts in a mid-nineteenth-century opera, were entrusted to tenors.

Gioacchino Rossini was born three months after Mozart died. The genre of opera seria was still popular when Rossini began composing operas in 1808, at the age of sixteen, but the male sopranos and altos associated with this genre in Mozart's time were by then a vanishing breed. The last illustrious castrato singer, Giovanni Battista Velluti, made his debut in 1800. In 1813, Rossini composed for Velluti one of his less successful operas, Aureliano in Palmira. But earlier in that same year, Rossini produced the two operas that marked the beginning of his international fame, Tancredi and L'italiana in Algeri. In the first of these, an opera seria based on a neoclassical tragedy by Voltaire, Rossini assigned the role of the male protagonist, a heroic warrior, to a (female) contralto. ${ }^{4}$ In the second one, even less conventionally, a contralto sang the leading female role in an opera buffa.

Contralto remained Rossini's preferred voice for his principal characters, either female or male. It seems safe to say that no other nineteenth- or twentieth-century composer wrote so many attractive contralto roles for

3 Alfred Einstein, Mozart: His Character, His Work, trans. Arthur Mendel and Nathan Broder (New York: Oxford University Press, 1962), 398.

4 The tradition of the primo musico, a woman (rather than a primo uomo) singing a leading male part such as would have been earlier assigned to a castrato, was a little older than SK here implies, and was not by any means peculiar to Rossini. The subject had not been extensively researched as of 1986, when SK was writing this, but has been since as part of the general burgeoning of interest in sexual and gender issues in theater and opera in response to what Heather Hadlock called "the 'first wave' of Anglo-American feminist opera studies," sparked by the appearance in English of Catherine Clément's L’opéra; ou, La défaite des femmes (Paris: B. Grasset, 1979), as Opera, or, The Undoing of Women, trans. Betsy Wing (Minneapolis: University of Minnesota Press, 1988). For an overview, see Hadlock's "Women Playing Men in Italian Opera, 1810-1835," in Women's Voices across Musical Worlds, ed. Jane A. Bernstein (Boston: Northeastern University Press, 2003), 285-307 (the quoted phrase is on p. 285). - Ed. 
his heroines (Rosina in II barbiere di Siviglia, sometimes transposed for a coloratura soprano in later times, but originally a contralto, and $\mathrm{La}$ Cenerentola, to name the two most popular ones) or for his romantic young heroes. Contraltos in "trouser roles" are of course familiar from later opera. Now and then we hear a contralto heroine, such as Donizetti's La favorita and, of course, Bizet's Carmen. But after Rossini's time, these were exceptional cases. In most nineteenth-century operas, contraltos were cast as mothers, the heroine's rivals, gypsies, seeresses, or attendants. Only Mikhail Glinka followed Rossini's example by casting contraltos as young men in both of his completed operas (Vanya in A Life for the Tsar and Ratmir in Ruslan and Lyudmila) and, what's more, he gave each of them one of the most attractive arias in their respective operas. ${ }^{5}$

One cause for Rossini's predilection for the contralto must have been the availability of a number of illustrious singers capable of performing brilliant coloratura passages in the lower range of a female voice (in the eighteenth century, the speciality of castrato altos). Among them were Adelaide Malanotte, the first Tancredi; Marietta Marcolini, who created contralto roles in four of Rossini's major operas; and Rosa Mariani, for whom he wrote the part of Arsace in his Semiramide. Yet when Rossini chose to marry an opera singer, it was not a contralto but a coloratura soprano, Isabella Colbran. ${ }^{6}$ His younger contemporary, the French poet, novelist, and theater critic Théophile Gautier, who wrote a remarkable eulogy to the contralto voice in his poem "Contralto" (the subject of the present paper), came to appreciate that type of voice only gradually and for personal as well as artistic reasons.

In his capacity as journalist and critic, Gautier had occasion to praise repeatedly the talents of various members of the illustrious Italian clan of Grisi, specifically the celebrated soprano Giulia Grisi and her contralto

5 Of the two Glinka roles adduced, only Ratmir belongs to the tradition under discussion. Women sopranos or altos singing boys' roles has lasted up to the present, and there are examples in many famous later operas, including Meyerbeer's Les huguenots (Page), Verdi's Un ballo in maschera (Oscar), Musorgsky's Boris Godunov (Tsarevich), Debussy's Pelléas et Mélisande (Yniold), and Strauss's Der Rosenkavalier (title role) and Ariadne auf Naxos (Composer), to mention a few.-Ed.

6 On the singers of Rossini's time and his relationships with them, I used Richard N. Coe's extensive annotations and detailed index in his translation of Stendhal's Life of Rossini (New York: Orion Press, 1970) and Herbert Weinstock, Rossini (New York: Alfred A. Knopf, 1968). 
sister, Giuditta. (It was for them that Vincenzo Bellini composed the parts of Juliet and Romeo in his opera I Capuleti e $i$ Montecchi, in which they excelled; the sisters were also noted for portraying the two lovers in Rossini's Bianca e Falerio. $)^{7}$ Gautier praised the beauty of Giulia Grisi's face and body in several texts, most notably in the preface to his novel Mademoiselle de Maupin. But it was Giulia's and Giuditta's cousin, the ballerina Carlotta Grisi, who turned out to be possibly the greatest love of Gautier's life. It was for Carlotta Grisi that Gautier created the scenario for the ballet Giselle (1841), in which she acquired worldwide fame and which is one of the earliest ballets to retain its place in the repertory to this day. In 1843, Gautier provided Carlotta Grisi with her second greatest success, $L a$ péri, a work that was widely danced throughout Europe for the rest of the nineteenth century.

Yet, while the ballerina was grateful to Gautier for his ballet scenarios and for his worshipful reviews of her dancing, she insisted that they remain good friends and nothing more. ${ }^{8}$ She was married to her choreographer and dancing partner Jules Perrot in what was apparently a marriage of convenience. When she was ready to move away from Perrot, it was not in the direction of Gautier that she went, but rather to Switzerland, where a wealthy member of the Radziwill family established her in a magnificent villa. Unable to reciprocate Gautier's passion, Carlotta Grisi did the next best thing: she introduced him to her younger sister Ernesta, a budding contralto who was later to become a noted specialist in trouser roles in Rossini's operas. Portraits of Ernesta Grisi show her as a shorter

7 On the repertoire of Giulia and Giuditta Grisi, see Teatral'naia entsiklopediia (Moscow: Sovetskoe entsiklopediia, 1961-67), vol. 2, columns 146-47.

8 The biographers of Carlotta Grisi (Serge Lifar, Carlotta Grisi [Paris: Albin Michel, 1941], 43) and of Gautier (Joanna Richardson, Théophile Gautier: His Life and Times [London: Max Reinhardt, 1958], 48-49 and passim) maintain that the relationship between the poet and the dancer was platonic. Edwin Binney 3rd, in his highly informative Les ballets de Théophile Gautier (Paris: Librairie Nizet, 1965), originally a Harvard dissertation, cites these and numerous other sources which all testify that Gautier's passion for Carlotta Grisi was not reciprocated except in terms of friendship (pp. 58-60). Binney nevertheless goes on to speculate that physical intimacy between them is within the realm of possibility, because "une ballerine de l'Opéra pleine d'ambition ne pouvait manquer de voir quel appui pouvait lui donner un critique influent" (p. 60). This kind of argument, based on the premise "it could have happened therefore it certainly did," reminiscent of recent conjectures about Chaikovsky's supposed suicide, is not otherwise typical of Binney's excellent book. 
and stockier version of her dancing sister, to whom she bore an uncanny facial resemblance. In the spring of 1844, Théophile Gautier and Ernesta Grisi became lovers.

Gautier never married. His other love affairs, documented by his biographers, were more or less transient, ending after a year or two. But he and Ernesta Grisi were to stay together for twenty-two years. She was the mother of his daughters Judith and Estelle Gautier, who grew up to marry distinguished men of letters (Judith Gautier eventually became a noted writer in her own right). In Joanna Richardson's words, Ernesta provided Gautier with "the old domestic security, the pampering he had known as a boy." While continuing her own musical career, she relieved the frequently impractical poet of household chores and financial worries by taking care of such matters herself. She was also reportedly a magnificent cook. It was shortly after the birth of their second daughter in November 1847 that Gautier expressed his love for Ernesta in the somewhat ambiguous eulogy to her voice, published in December of the same year and later included in his collection Émaux et camées. ${ }^{10}$

\section{CONTRALTO}

1 On voit dans le Musée antique, Sur un lit de marbre sculpté, Une statue énigmatique D’une inquiétante beauté.

2 Est-ce un jeune homme? est-ce une femme, Une déesse, ou bien un dieu? L'amour, ayant peur d'être infâme, Hésite et suspend son aveu.

3 Dans sa pose malicieuse, Elle s'étend, le dos tourné Devant la foule curieuse, Sur son coussin capitonné.

9 Richardson, Gautier, 53-54.

10 For the publication history of "Contralto," see the commentary by Claudine GothotMersch in Théophile Gautier, Émaux et camées, ed. Claudine Gothot-Mersch (Paris: Gallimard, 1981), 236-38. 
4 Pour faire sa beauté maudite, Chaque sexe apporta son don. Tout homme dit: C'est Aphrodite! Toute femme: C'est Cupidon!

5 Sexe douteux, grâce certaine, On dirait ce corps indécis Fondu, dans l'eau de la fontaine, Sous les baisers de Salmacis.

6 Chimère ardente, effort suprême De l'art et de la volupté, Monstre charmant, comme je t'aime Avec ta multiple beauté!

7 Bien qu'on défende ton approche, Sous la draperie aux plis droits Dont le bout à ton pied s'accroche, Mes yeux ont plongé bien des fois.

8 Rêve de poëte et d'artiste, Tu m'as bien des nuits occupé, Et mon caprice qui persiste Ne convient pas qu'il s'est trompé.

9 Mais seulement il se transpose, Et, passant de la forme au son, Trouve dans sa métamorphose La jeune fille et le garçon.

10 Que tu me plais, ô timbre étrange!

Son double, homme et femme à la fois,

Contralto, bizarre mélange,

Hermaphrodite de la voix!

11 C’est Roméo, c'est Juliette, Chantant avec un seul gosier; Le pigeon rauque et la fauvette Perchés sur le même rosier; 
12 C'est la châtelaine qui raille Son beau page parlant d'amour; L'amant au pied de la muraille, La dame au balcon de sa tour;

13 Le papillon, blanche étincelle, Qu'en ses détours et ses ébats Poursuit un papillon fidèle, L'un volant haut et l'autre bas;

14 Lange qui descend et qui monte Sur l'escalier d'or voltigeant; La cloche mêlant dans sa fonte La voix d'airain, la voix d'argent;

15 La mélodie et l'harmonie, Le chant et l'accompagnement; A la grâce la force unie, La maîtresse embrassant l'amant!

16 Sur le pli de sa jupe assise, Ce soir, ce sera Cendrillon Causant près du feu qu'elle attise Avec son ami le grillon;

17 Demain le valeureux Arsace A son courroux donnant l'essor, Ou Tancrède avec sa cuirasse, Son épée et son casque d'or;

18 Desdemona chantant le Saule, Zerline bernant Mazetto, Ou Malcolm le plaid sur l'épaule; C'est toi que j'aime, ô contralto!

19 Nature charmante et bizarre Que Dieu d'un double attrait para, Toi qui pourrais, comme Gulnare, Être le Kaled d'un Lara, 


\section{Et dont la voix, dans sa caresse, Réveillant le cour endormi, Mêle aux soupirs de la maîtresse L'accent plus mâle de l'ami!}

In the not entirely sympathetic preface to her excellently annotated edition of Émaux et camées, Claudine Gothot-Mersch wrote that "while woman is everywhere present [in this collection], love is nowhere to be found; what dominates is the madrigal." 11 In "Contralto," love is definitely present, though it is brought in through a tortuous path. His preference for the unconventional (or, perhaps, his horror of appearing conventional) led Gautier to filter the timbre of his life companion's voice and the cozy domesticity he enjoyed with her through the prism of French Romanticism's most daring theme, that of androgyny. ${ }^{12}$ Gautier's contemporary Honoré de Balzac dealt with this theme in Sarrazine (1830) and Séraphita (1835) and Gautier himself touched on it in his novel Mademoiselle de Maupin in a somewhat gingerly manner. "Contralto" comes to grips with androgyny more boldly. In Mademoiselle de Maupin Gautier shielded himself by appealing to the authority of Shakespeare, unchallengeable for the Romantics. The most explicitly androgynous scenes of the novel take place during rehearsals of As You Like It, whose action these scenes parallel. The central theme and metaphor of "Contralto" is the sexual ambiguity of contralto in the operas of Rossini.

The entire poem is, in fact, an extended metaphorical equation between the ability of contralto singers in Rossini's operas to portray both female and male characters and the ancient myth of Hermaphroditus, the offspring of Hermes and Aphrodite, who possessed the sexual characteristics of both a man and a woman. But the components of this equation are presented in reversed order. The contralto voice which the poem eulogizes is first mentioned in the tenth of the poem's twenty stanzas. The first nine stanzas develop an idea which, were it stated in prose and not in Gautier's elegant verse, would find little agreement on the part of most readers. It is

11 Ibid., 12.

12 Gothot-Mersch calls the subject of hermaphroditism the "thème d'époque" (ibid., 237). 
the assertion that depictions of hermaphroditism in the visual arts are erotically attractive for both men and women. Though it may be true that some female singers charm their audiences in trouser roles (the reverse disguise, male singers in female roles, has been relegated to broad comedy in nineteenth- and twentieth-century opera: the mother in Donizetti's Convenzione e inconvenzione teatrale or the cook in Prokofiev's Love for Three Oranges), what Gautier proclaims is the universal attractiveness of a nude hermaphroditic body. This declaration, deliberately paradoxical, can be backed by the poet with only one instance and even that one derived from mythology, the Ovidian myth of the nymph Salmacis who fell in love with Hermaphroditus and persuaded the gods to fuse their two bodies together. Gautier evokes this myth in the fifth stanza of his poem.

"Contralto" begins with a description of a concrete work of art, the ancient marble statue of the Sleeping Hermaphrodite at the Louvre $\mathrm{Mu}$ seum in Paris. In Gautier's time, as it still is today, this sculpture was placed in a corner with its back to the spectators and surrounded by railings which prevented them from seeing the front of the body. ${ }^{13}$ This placement enables Gautier to speculate on the ambiguous fascination of the statue for both the male and the female visitors to the museum (stanzas two through four). Then, after the Ovidian reference, stanzas seven and eight tell of the poet's own love for the sculpture and for what it represents, an attraction that is intensified by the prohibition against seeing the whole of the statue and by the impossibility of giving any concrete expression to this love for a chimera ("chimère ardente, effort suprême / De l'art et de la volupté").

Stanza nine is the turning point of the entire poem, a pivot on which it revolves, making the preceding stanzas a metaphor for the stanzas that follow. This is achieved by use of synesthesia, a device favored by the Symbolist poets who followed Gautier and acknowledged him as their master, far more than by the Romantics to whose generation he belonged. Through synesthesia ("passant de la forme au son") the poet converts, in the tenth stanza, the visual charm of the statue of the hermaphrodite into its aural equivalent, a woman's contralto voice. This voice is something

13 In a critical article published in 1839, Gautier advised the visitors at the Louvre Museum to wait until the guard's back is turned and then to examine the statue of the Sleeping Hermaphrodite ("this graceful chimera, a dream of antiquity") from all sides. Cited by Gothot-Mersch, ibid., 237. 
a man may love without ambiguity. Therefore the negative epithets that were intermingled with eulogies in the first ten stanzas ("amour ... infâme," "pose malicieuse," "beauté maudite," "monstre charmant"), which all referred to the hermaphrodite, are absent in the last ten stanzas of the poem, devoted to the contralto voice.

The theme of operatic singing enters the poem in the eleventh stanza with a reference to a non-Rossinian opera. Romeo and Juliet in that stanza, "chantant avec un seul gosier," evoke a celebrated passage in Bellini's I Capuleti e i Montecchi which the soprano Juliet and the contralto Romeo sing in unison. This unison was much admired by Hector Berlioz and it was, according to Andrew Porter, obliterated in the twentieth-century performances of Bellini's opera prior to the 1970s, which transposed Romeo's music an octave down for a tenor voice, making the unison mentioned by Gautier impossible to perform. ${ }^{14}$

The four stanzas that follow this first operatic example enumerate a series of images or situations meant to illustrate the contralto's ability to sing in both the high and the low register: a raucous pigeon and a warbler perched on the same rosebush; a lover whose lady is above him on her balcony (Romeo and Juliet again); two butterflies, flying one above the other; an angel (apparently from Jacob's dream in the Old Testament) which descends and ascends a shimmering golden ladder; and, finally, a church bell that sounds "the voice of brass, the voice of silver." (Church bells and the alloys from which they are made were to interest Gautier during his visit to the Moscow Kremlin, some ten years after he wrote "Contralto.")

The vertical axis along which the imagery of stanzas eleven to fourteen is deployed serves to pay homage to the range and versatility of Ernesta Grisi's voice. In stanza fifteen there are no longer any contrasts. Instead, these four lines offer images of fusion between melody and harmony, singing and accompaniment, strength and grace, all culminating in a woman embracing the man she loves. The madrigal to Ernesta could have ended at this point. But Gautier preferred to make it more personal by enumerating the roles of the Rossinian repertoire in which she excelled (plus Zerlina in Mozart's Don Giovanni, a role that can be comfortably

14 Andrew Porter, Music of Three Seasons: 1974-1977 (New York: Farrar, Straus and Giroux, 1978), 175-78. 
sung by either a soprano or a mezzo): the protagonist of La Cenerentola and Desdemona in Rossini's Otello singing her song of the willow. Alongside these female roles of Cinderella, Desdemona and Zerlina, Gautier also lists three heroic male characters, whose music was scored by Rossini for the female contralto voice: Arsace in Semiramide, Tancredi, and Malcolm in La donna del lago (after Sir Walter Scott's poem The Lady of the Lake). ${ }^{15}$ This enumeration is crowned by direct apostrophizing of the singer who performed all these roles: “C'est toi que j’aime, ô contralto!" Stanzas nineteen and twenty form a brief epilogue which alludes to two popular verse tales by Byron, Lara, in which the male protagonist's beloved was disguised as a young man, and The Corsair, in which she appeared in Turkish female garb. The final two lines of the poem neatly define Ernesta Grisi's function in Gautier's life: she was not only a woman who loved him, but one who, through her support, practicality, and lack of possessiveness, acted as a loyal male friend might have done.

After Gautier's death in 1872 and especially at the turn of the century, his literary reputation, so secure in his lifetime, suffered a precipitous decline in his native France. ${ }^{16}$ This situation still continued in the first two decades of the twentieth century, at the time when Gautier's poetry came to be valued by poets of the English-speaking countries such as Ezra Pound and T. S. Eliot and by the Russian Acmeists, Nikolai Gumilyov above all. ${ }^{17}$ In his 1911 essay on Gautier, Gumilyov argued that Gautier, because of the perfection of his form and his refusal to join any school or

15 The roles of Tancredi, Arsace, and Malcolm were mentioned by Gautier in his article about the Paris debut of Pauline Viardot Garcia as the parts in which he would like to hear this singer. The article was published in 1839, five years before Gautier and Ernesta Grisi became lovers. Cited by Gothot-Mersch in Gautier, Émaux, 238.

16 On the decline of Gautier's reputation at the end of the nineteenth century owing to dismissive attitudes of such utilitarian French critics as Émile Faguet and on the subsequent revival of Gautier's popularity in France by the middle of twentieth century, see René Jasinski, “Situation de Théophile Gautier,” Europe (Paris), no. 601, a special issue devoted to Gautier (May 1979): 3-16.

17 On the chronology of the enthusiasm for Gautier's poetry on the part of English and American poets and of the Russian Acmeists, see Serge Fauchereau, "Où Pound et Eliot rencontrent Goumilev, Mandelstam et Akhmatova," in the issue of Europe cited in the previous note, 57-73. In addition to literary phenomena, Gautier's impact on Russian culture of the early twentieth century can be seen from the fact that two of the ballets with which Sergei Diaghilev's company conquered Paris, Le pavilion d'Armide (1909) and Le spectre de la rose (1911), were based on texts by Gautier. 
ideology, should be a model for Russian twentieth-century poets. In his Acmeist manifesto of 1913, Gumilyov placed Gautier's name next to those of Shakespeare, Rabelais and Villon. ${ }^{18}$ In 1914 came his translation of Émaux et camées, including "Contralto."

\section{КОНТРАЛЬТО}

1 Въ музеъ древняго познанья Лежитъ надъ мраморной скамьей Загадочное изваянье Съ тревожащею красотой.

2 То нъжный юноша? Иль дъва? Богиня, иль быть можетъ богъ? Любовь, страшась Господня гнъва, Дрожитъ, удерживая вздохъ.

3 Такъ вызывающе-лукаво, Оно повернуто спиной, Лежитъ въ подушкахъ величаво, Предъ любопытною толпой.

4 Ахъ, красота его обида И каждый полъ въ него влюбленъ, Мужчины върятъ: то Киприда! И женщины: то Купидонъ.

5 Невърный полъ, восторгъ безспорный, Сказали бъ, тьло-кипарисъ Растаяло въ водъ озерной Подъ поцълуемъ Салмасисъ.

6 Химера пламенная, диво Искусства и мечты больной, Люблю тебя я, звърь красивый, Съ твоей различной красотой.

18 See Gumilyov's essays "Nasledie simvolizma i akmeizm" and "Teofil' Got'e" in N. Gumilev, Sobranie sochinenii, 4 vols. (Washington: Victor Kamkin, 1962-68), 4:171-76 and 386-96, respectively. 
7 Хотя тебя ревниво скрыло

Съ прямыми складками сукно, Ненужно, грубо и уныло, Тобой любуюсь я давно.

8 Мечта поэта и артиста, Я по ночамъ въ тебя влюбленъ, И мой восторгъ, пускай нечистый, Не долженъ обмануться онъ.

9 Онъ только терпить превращенье, Переходя изъ формы въ звукъ, Я вижу новое явленье Красавица и съ нею другъ.

10 О какъ ты милъ мнъ, тембръ чудесный, Гдъ юноша съ женою слитъ, Контральто, выродокъ прелестный, Голосовой гермафродитъ!

11 То Ромео и то Джульета, Что голосомъ однимъ поютъ, Голубка съ голубемъ, до свъта Одинъ нашедшіе пріютъ.

12 То передразниваетъ дама

Въ нее влюбленнаго пажа, Любовникъ пъснь ведетъ упрямо, На башнъ вторитъ ей, дрожа.

13 То мотылекъ, что искрой бълой -Какъ летъ его неуловимъСпъшить за бабочкой несмълой, Онъ наверху, она подъ нимъ.

14 То ангелъ сходитъ и восходитъ По лъстницъ, чей блескъ-добро; То колоколъ, что звукъ выводитъ, Смъшавши мъдь и серебро. 
15 То связь гармоній и мелодій, То аккомпаниментъ и тонъ, То сила съ граціей въ природъ, Любовницы томящій стонъ.

16 Сегодня это Сандрильона Передъ привътнымъ камелькомъ, Шутящая непринужденно Съ пріятелемъ своимъ сверчкомъ.

17 Потомъ Арзасъ великодушный, Не могшій удержать свой гнъвъ, Или Танкредъ въ кольчугъ душной, Схвативъ свой мечъ и шлемъ надъвъ.

18 Поетъ Дездемона объ ивъ, Малькольмъ закутался въ свой пледъ; Контральто, нбтъ ни прихотливъй Тебя, ни благороднъй нбтъ.

19 Твоя загадочная чара Сильна приманкою двойной Ты снова можешь, какъ Гюльнара, Для Лары нъжнымъ быть слугой,

20 Въ чьей ръчи слиты потаенно, Чтобъ страсть была всегда жива, И вздохи женщины влюбленной И друга твердыя слова.

Gumilyov used the last and most complete of the six editions of Gautier's collection that were published under the poet's supervision between 1852 and $1872 .{ }^{19}$ Gumilyov's translation, Emali $i \mathrm{ka}$ -

19 The publication history and the contents of the six different editions of Émaux et camées that appeared in Gautier's lifetime are outlined by Gothot-Mersch in her "Notice," Gautier, Émaux, 221-22. 
$m e i,{ }^{20}$ could have served as a model of fidelity and empathy were it not marred by some spectacular misreadings. These begin in the prefatory sonnet, where the Persian word for hoopoe, "Hudhud" (apparently related etymologically to the Russian "udod"), cited by Gautier from Goethe's West-östlicher Divan, was mistaken by Gumilyov for a woman's proper name ("Nota le chant qu'Hudhud soupire" was rendered as "Pel o Gudut, zhivushchei siro"). But on the whole, Gumilyov's version of Gautier's collection shows both a profound affinity for the French poet and a great deal of technical resourcefulness. The French octosyllabic verse with cross rhymes that alternate feminine and masculine endings, in which the overwhelming majority of Gautier's poems is couched, is accurately conveyed by its Russian equivalent, quatrains of the familiar iambic tetrameter with an analogous rhyme scheme.

Gumilyov's version of "Contralto" is free of glaring misreadings of the kind cited above. There is a certain vagueness in a few lines, caused by lack of awareness of specific realia mentioned by Gautier. Thus, the collection of ancient art in the Louvre in the first line of the poem is rendered somewhat pompously as "In the museum of ancient cognition" ("V muzee drevniago poznan'ia"). The adjective "privetnyi," "cozy" or "affable," is not the right one for the fireplace that Rossini's Cenerentola is forced to tend by her brutish stepfather (sixteenth stanza). In the eighteenth stanza, Malcolm Graeme, about whom Scott's original poem said that "the belted plaid and tartan hose / Did ne'er more graceful limbs disclose," merely wore his plaid on his shoulder in Gautier. Gumilyov, however, mistaking the English and French "plaid" for the Russian "pled," which means a blanket or a lap-robe, has Malcolm disappear from view, limbs and all, by wrapping himself up in that blanket ("Mal'kol'm zakutalsia v svoi pled"). This eighteenth stanza is the one least faithfully rendered, because not only Malcolm vanishes, but so do the Mozartian reference to Zerlina and Masetto and Gautier's declaration of love for his mistress in the last line.

The greatest divergences between Gautier's and Gumilyov's texts occur in the first half of the poem, where the poet proclaims his attraction

20 Teofil' Got'e, Emali i kamei, trans. N. Gumilev (St. Petersburg: M. V. Popov, 1914). I am grateful to the Houghton Library of Harvard University for making a copy of this rare edition available to me. [Gumilyov's translation can now be viewed through the Internet from a copy at the University of Wisconsin: http://babel.hathitrust.org/cgi/ pt?id=wu.89010608297.-Ed.] 
for the statue of the hermaphrodite, but qualifies this admission by a series of negative epithets. Gumilyov quite systematically intensifies the negativity. In stanza two, "peur d'être infâme" is "strashas' Gospodnia gneva" ("fearing the wrath of God") in Russian. Gautier says that the statue is a product "de l'art et de la volupté" (sixth stanza), but Gumilyov has "iskusstva i mechty bol'noi," "of art and of a sick [pathological] yearning." In the seventh stanza, where the poet admits to having stolen glances at the statue many times, Gumilyov adds three adverbs that do not correspond to anything in Gautier's text: "nenuzhno, grubo i unylo" ("uselessly, coarsely and despondently"). The next stanza continues describing the poet's attraction to the statue. Again Gumilyov adds a qualifier not present in Gautier: "puskai nechistyi" ("albeit impure"), which condemns the attraction far more strongly than the original text ever did. Worst of all, in the tenth stanza, where the subject of the poem has switched from the statue of the hermaphrodite to the contralto voice, which Gautier calls a "bizarre mélange," Gumilyov translates these words oxymoronically as "vyrodok prelestnyi" ("a charming degenerate").

All this intensification is especially strange when one remembers that the themes of androgyny and hermaphroditism were treated by Gumilyov in his own writings on at least six occasions and without condemnation. ${ }^{21}$ There are other nits to pick in Gumilyov's translation if one is so inclined: the confusion between the two verse tales by Byron in the penultimate

21 Androgynous situations or characters appear in his poems "Poedinok" [Single combat] (possibly inspired by the battle between Tancredi and Clorinda in Tasso) and "Androgin" [The androgyne], both included in his verse collection Zhemchuga [Pearls], 1907-10. An androgyne also appears in Gumilyov's short story "Puteshestvie $\mathrm{v}$ stranu efira" [Voyage to the land of ether]. Lesbianism is the theme of his poem "Zhestokoi" [To a cruel woman], and male homosexuality appears in the poem "Liubov"' [Love] and is alluded to in the dialogue between the poet Hafiz and his tame birds in the last scene of Gumilyov's puppet play Ditia Allakha [The child of Allah]. With the possible exception of "Liubov'," Gumilyov treated these topics in nonjudgmental or affirmative terms. See Gumilev, Sobranie sochinenii, 1:98-99, 111-12 and 174-76 for the poems cited above. The short story is in $4: 68-80$ and the play Ditia Allakha is in 3:95-135.

On the themes of androgyny and hermaphroditism in the poetry, fiction, and philosophy of the Russian Silver Age (the Symbolist and Postsymbolist periods), see Olga Matich, "Androgyny and the Russian Religious Renaissance," in Western Philosophical Systems in Russian Literature: A Collection of Critical Studies, ed. Anthony M. Mlikotin (Los Angeles: University of Southern California Press, 1979), 165-75; and "Androgyny and the Russian Silver Age," Pacific Coast Philology 14 (1979): 42-49. 
stanza or the two occasions where new imagery was brought in so as to accommodate the rhyme: the body of Hermaphroditus is compared to cypress wood, "kiparis," so as to rhyme with Salmacis (fifth stanza); and the biblical angel's ladder in stanza fourteen is said to glitter with goodness, "dobro," so as to provide a rhyme with silver in the church bell, "serebro." There are also instances where Gumilyov took advantage of Russian grammatical gender, more strongly expressed than the French one, to improve Gautier's imagery. The pigeon and the warbler in stanza eleven are replaced by a more likely pair, male and female pigeons. The two butterflies in stanza thirteen also get to be sexually differentiated owing to the availability in Russian of two words for butterfly: "babochka," which is feminine, and "motylek," which is masculine.

And yet, despite these divergences from the original text, Gumilyov's translation is a masterful poem. Read as a whole, it does convey Gautier's elegance and his filigreed mastery of poetic craft. No rhymed translation can ever duplicate the original in toto. Gumilyov's version does the next best thing: it catches and reproduces the ardor, the ambiguity, and the deliberate perversity of this hymn to a particular timbre of the female voice, the contralto, which Rossini loved creatively, Gautier loved personally, and Gumilyov came to love through its reflection in his favorite poet's art. 